\title{
Establishment of Conditions for Long-Term Maintenance of Primary Embryonic Cell Cultures from Olive Flounder Paralichthys olivaceus
}

\author{
†Ju-Won Kim, Ja Young Cho, Dong-Gyun Kim, Bo-Hye Nam, Eun-Soo Nho, \\ Bong-Seok Kim, Young-Ok Kim, and Hee Jeong Kong \\ Biotechnology Research Division, National Institute of Fisheries Science, Busan 46083, Korea
}

Received: September 1, 2020

Revised: September 8, 2020

Accepted: September 20, 2020

${ }^{+}$Corresponding author

Ju-Won Kim

Biotechnology Research Division,

National Institute of Fisheries Science (NIFS),

Busan 46083, Korea.

Tel: +82-51-720-2457

Fax: +82-51-720-2456

E-mail:ogamzar@korea.kr

Copyright $\odot 2020$ The Korean Society of Developmental Biology.

This is an Open Access article distributed under the terms of the Creative Commons Attribution Non-Commercial License (http://creativecommons.org/licenses/ by-nc/4.0/) which permits unrestricted non-commercial use, distribution, and reproduction in any medium, provided the original work is properly cited.

ORCID

Ju-Won Kim

https://orcid.org/0000-0002-4220-711X Ja Young Cho

https://orcid.org/0000-0002-4549-7570 Dong-Gyun Kim

https://orcid.org/0000-0002-0229-5469 Bo-Hye Nam

https://orcid.org/0000-0002-7461-2099

Eun-Soo Nho

https://orcid.org/0000-0003-3880-5050

Bong-Seok Kim

https://orcid.org/0000-0002-5997-8113

Young-Ok Kim

https://orcid.org/0000-0001-8719-0764

Hee Jeong Kong

https://orcid.org/0000-0001-6524-6544

Conflict of interests

The authors declare no potential conflict of interest.

\section{Abstract}

Primary cell culture is a sufficient method frequently used to study the cellular properties and mechanisms of isolated cells in a controlled environment. In this study, an embryonic cell line (FGBC8) derived from the blastula stages of embryos of olive flounder Paralichthys olivaceus was developed. Furthermore, conditions for optimal long-term maintenance of this primary embryonic cell culture were investigated. Morphologically, FGBC8 cells were composed primarily of epithelial-like cells. FGBC8 cells were subcultured for $>160$ passages over $\sim 830$ days. The doubling time of FGBC8 cells was $73.8 \mathrm{~h}$, and the modal diploid chromosome number was 48. FGBC8 cells transfected with green fluorescence protein (GFP)-expression plasmid exhibited a strong signal $48 \mathrm{~h}$ after transfection. Consequently, we demonstrated that fish serum is a crucial supplement for the long-term survival and maintenance of comparable morphology in these primary embryonic cells. Our results can be used as a guide for primary embryonic cell cultures for other fish species and may be useful for cell biotechnological applications.

Keywords: Olive flounder, Embryo, Primary cell culture, Long-term maintenance

\section{INTRODUCTION}

Primary cell cultures are vital tools for the functional evaluation of biological substances and characterization of specific biological activities (Wang et al., 2020). Despite vast differences in the physiologies of mammals and fish, primary cell culture protocols for fish are often based on mammalian culture conditions with only minor modifications (Ager-Wick et al., 2018).

Primary culture of fish cells has been used as an ideal model for various studies, such as substrate utilization (Hasoon, 2018), xenobiotic metabolism, thermal stress, and monitoring of aquatic pollution (Wang et al., 1985; Ghosh et al., 1995). Recently, techniques have been developed for primary culture of fish cells, but the optimal protocols and conditions necessary for disaggregation, seeding, maintenance, and culture of cells have varied (Hasoon, 2018).

Moreover, using several organ or tissue from olive flounder, several cell lines have been developed: flounder gill (FG)-9307 cells (Tong et al., 1998), hirame natural embryonic cells (HINAE) (Kasai \& 
Acknowledgements

This research was supported by a research project (R2020020) managed by the National Institute of Fisheries Science (NIFS).

\section{Authors' contributions}

Conceptualization: Kong $\mathrm{HJ}$.

Data curation: Cho JY.

Formal analysis: Nho ES.

Methodology: Nam BH.

Software: Kim DG.

Validation: Kim YO.

Investigation: Kim JW.

Writing - original draft: Kim JW.

Writing - review \& editing: Kim BS.

Ethics approval

This article does not require IRB/IACUC approval because there are no human and animal participants.
Yoshimizu, 2001), flounder spleen and gill cells (Kang et al., 2003), flounder embryonic cells (Chen et al., 2004), and flounder brain cells (Zheng et al., 2015). Establishing various useful cell lines from olive flounder is important for basic research and biotechnological applications.

Primary cell culture is a sufficient method frequently used to study the cellular properties and mechanisms of isolated cells in a controlled environment (Ager-Wick et al., 2018). However, due to insufficient information on universally applicable cell culture conditions and protocols, welldescribed cell culture methods for marine fish are still limited.

Here, we investigated the conditions suitable for long-term maintenance of a primary embryonic cell culture. The cell line was also characterized chromosomal abnormalities, growth rate, and transfection capability in the present study.

\section{MATERIALS AND METHODS}

\section{Primary cell culture and media supplements}

Embryonic cells were obtained by primary cell culture following methods in our previous study (Kim et al., 2018). Briefly, blastula-stage embryos from olive flounder were collected after $8 \mathrm{~h}$ in seawater at $18^{\circ} \mathrm{C}$ post-fertilization and prepared as follows. For embryonic cell harvest, $60-70$ embryos were treated with antibiotics (1×), washed with DPBS (Gibco, Gaithersburg, MD, USA), and homogenized. The chorion membranes and cell debris were eliminated using a $40-\mu \mathrm{m}$ cell strainer. For the single cells collection, the homogenate was centrifuged at $229 \times \mathrm{g}$ for $15 \mathrm{~min}$ at $20^{\circ} \mathrm{C}$, and supernatant was discarded. After several washes with growth medium (GM), the cells were moved to GM in a fresh cell culture flask (surface area: $25 \mathrm{~cm}^{2}$ ) (Corning, Corning, NY, USA).

Leibovitz's L-15 complete GM (L-15; Gibco), supplemented with fetal bovine serum (FBS; Gibco), antibiotic-antimycotic (AA; Gibco), and fish serum (FS) from olive flounder, and growth factor (GF) were added to conduct the subculture according to the methods reported in our previous study (Kim et al., 2018). To prepare the FS, blood samples were collected from the caudal vein of three olive flounder and allowed to clot at $4^{\circ} \mathrm{C}$ for $4 \mathrm{~h}$. After centrifugation, the serum was moved into new flash tubes, heat-inactivated in a water bath at $56^{\circ} \mathrm{C}$ for $30 \mathrm{~min}$, filter-sterilized $(0.2$ $\mu \mathrm{m}$ ), and stored at $-20^{\circ} \mathrm{C}$ until use. FS concentration was determined via Warburg-Christian assay using a NanoVue spectrophotometer (GE Healthcare, Chicago, IL, USA) (data not shown).

\section{Investigation of long-term maintenance conditions}

\section{1) Subculture}

Olive Flounder Embryonic Cell 18, named OFEC18-FGBC (FGBC8), was cultured at $20^{\circ} \mathrm{C}$ in an incubator with an air atmosphere, and the medium was changed every 2-3 days. To conduct the subculture, culture medium was prepared as GM (L-15 medium containing 10\% FBS and $2 \% \mathrm{AA}$ ) with $1 \% \mathrm{FS}$ and $0.1 \%$ GF (basal fibroblast GF [bFGF]; Corning). Upon reaching 90\% confluence, the cells were subcultured at a ratio of 2:3 following our previous study (Kim et al., 2018) with minor modification. Briefly, FGBC8 cells were washed twice with GM (without FS and GF) and dissociated in trypsin- ethylenediaminetetraacetic acid (trypsin-EDTA [TE]; Gibco) for $3 \mathrm{~min}$ at room temperature and centrifuged at $330 \times \mathrm{g}$ for $5 \mathrm{~min}$ at $20^{\circ} \mathrm{C}$. The TE solution was removed, and single cells were suspended with fresh culture medium and transferred to a $25 \mathrm{~T}$ cell culture flask (Corning).

For cryopreservation of embryonic cells, cultured cells were harvested with Bambanker stock 
solution (Lymphotec, Fuyuki, Japan).

\section{2) Adjustment of medium supplements}

The effect of adjusting medium supplements was investigated to explore the optimal conditions for long-term maintenance of the embryonic cells. Cell culture medium was used as described above. When exchanging the cell culture medium in the subculture, FS was gradually decreased from $1.0 \%$ to $0 \%$, while $\mathrm{GF}$ was decreased from $0.1 \%$ to $0 \%$. The survival, growth, and morphology of FGBC8 cells were then visualized under a fluorescence microscope (Axio Vert A1; ZEISS, Oberkochen, Germany).

\section{Characterization of embryonic cells}

\section{1) Cell growth curve}

To measure cell growth, we used cell proliferation assays and general cell counting methods. First, a proliferation assay was conducted using a Premix WST-1 Cell Proliferation Assay System (Takara, Kusata, Japan) following a previously established method with minor modifications (Kim et al., 2013). The FGBC 8 cells were adjusted to $6 \times 10^{4}$ cells/well in a 24 -well plate (Corning) and incubated at $20^{\circ} \mathrm{C}$ for 4 days. Blank controls with GM alone were also included.

For the proliferation assay, $10 \mu \mathrm{L}$ of WST-1 reagent was added to each well following incubation. The absorbance was determined using a Victor 3 microplate reader (PerkinElmer, Waltham, MA, USA) at a test wavelength of $450 \mathrm{~nm}$ and a reference wavelength of $690 \mathrm{~nm}$.

For general cell counting, the FGBC8 cells were suspended in trypsin-EDTA for 4 min and centrifuged for $5 \mathrm{~min}$ at $330 \times \mathrm{g}$ at $20^{\circ} \mathrm{C}$. Trypsin-EDTA was then replaced with GM $(1 \mathrm{~mL})$. Cells were counted daily using a Bright-Line hemocytometer (Sigma-Aldrich, St. Louis, MO, USA). Doubling time was calculated using the linear part of the growth curve as follows: doubling time $=$ duration $\times \log (2) \div[\log ($ final conc.) $-\log$ (initial conc.) $]$. At the same time, the morphology of FGBC8 cells was observed using an IncuCyte S3 Live-cell Analysis System (Sartorius, Bohemia, NY, USA) for 4 days.

Data were analysed by one-way analysis of variance (ANOVA) using SPSS version 19 software (SPSS, Chicago, IL, USA). All samples were analysed in triplicate and the results are reported as the mean $\pm \mathrm{SD}$.

\section{2) Chromosome analysis}

FGBC8 cells were used for chromosome analysis following a previously published method (Kim et al., 2018) with slight modifications. Briefly, cells were treated with $1 \mu \mathrm{g} / \mathrm{mL}$ colchicine (Sigma-Aldrich) for $2 \mathrm{~h} 30 \mathrm{~min}$ at $20^{\circ} \mathrm{C}$, harvested by scraping the flask using a sterile cell scraper (length: $290 \mathrm{~mm}$, blade: $20 \mathrm{~mm}$ ), suspended in $0.075 \mathrm{M} \mathrm{KCl}$, and incubated for $20 \mathrm{~min}$ at room temperature. The $\mathrm{KCl}$ was discarded, and $4 \mathrm{~mL}$ methanol:acetic acid (3:1) fixative solution was added gently but rapidly using a glass Pasteur pipette $(230 \mathrm{~mm}$; Volac, Orwell, UK). The cells were incubated at room temperature for $30 \mathrm{~min}$ and $2 \times$ fixative solution was added. The cells were dropped onto a fixative solution-treated slide glass and stained for 8 min with 8\% Giemsa (Gibco). Lastly, chromosomes of metaphase cells were visualized using a microscope (DE/EM6000B; Leica, Wetzlar, Germany) with oil-immersion optics (Merck KGaA, Darmstadt, Germany) at 1,000× magnification.

\section{3) Transfection}

To determine the transfection efficiency of the FGBC8 cells, the transfection assay was 
conducted according to the methods reported in our previous study (Kim et al., 2018). FGBC8 cells were seeded at a density of $7 \times 10^{4}$ per well in 24 -well plates at $20^{\circ} \mathrm{C}$. Cell monolayers $(80 \%$ confluent) were transfected with pEGFP-c1 plasmid DNA and an expression plasmid using a JetPEI kit (Polyplus, New York, NY, USA) according to the manufacturer's instructions. Each well contained $500 \mathrm{ng}$ pEGFP-c1 plasmid DNA in $150 \mathrm{mM} \mathrm{NaCl}$ (final volume: $50 \mu \mathrm{L}$ ) and $2 \mu \mathrm{L}$ JetPEI reagent in $150 \mathrm{mM} \mathrm{NaCl}$ (final volume: $50 \mu \mathrm{L}$ ). Green fluorescence signals were detected under a fluorescence microscope (Axio Vert A1; ZEISS) at $48 \mathrm{~h}$ post-transfection.

\section{RESULTS}

\section{Primary embryonic cell culture}

A new olive flounder cell line called OFEC18-FGBC (FGBC8) was developed by primary cell culture of blastula-stage embryos following methods in our previous study (Kim et al., 2018). To explore the conditions required for long-term maintenance, we produced other embryonic cell lines under various conditions using the same culture methods; however, all newly developed embryonic cell lines died (data not shown) except the FGBC8 cells. The first subculture was also achieved. Morphologically, the FGBC8 cells were composed primarily of epithelial-like cells (Fig. 1). To date, FGBC 8 cells have been subcultured for $>160$ passages over $~ 830$ days.

\section{Long-term maintenance conditions}

We investigated the effect of adjusting FS to elucidate the ideal conditions for long-term maintenance. Although FS was gradually decreased from $1.0 \%$ to $0 \%$, there was no effect on the survival of the tested cells (Fig. 2A). Conversely, when GF was decreased from $0.1 \%$ to $0.0 \%$, the cells died. However, when cells adjusted to 0\% FS were continuously subcultured (Fig. 2B), the survival rate gradually decreased until all were dead at 29 passages (data not shown). Therefore, we concluded that FS is a crucial supplement for the long-term survival and maintenance of comparable morphology of primary embryonic cells.

\section{Characterization of FGBC8}

FGBC8 cells grew evenly attached to the well surfaces within the $24 \mathrm{~h}$ after seeding. Cell
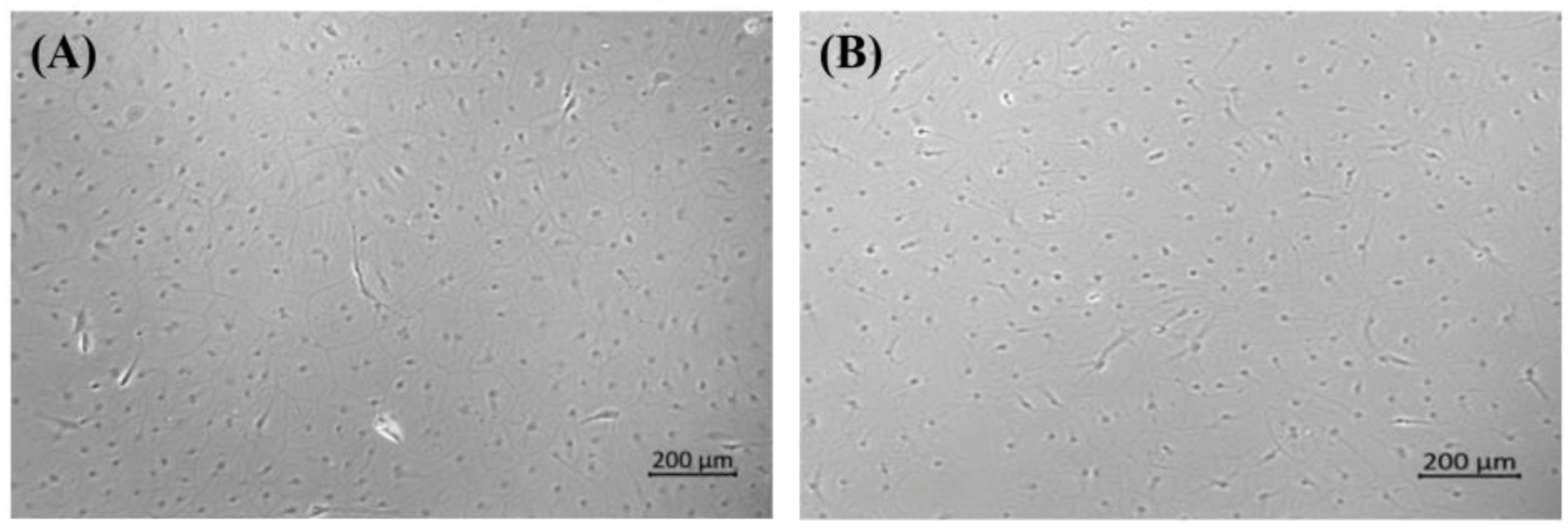

Fig. 1. The monolayers of FGBC8 cells. Morphological appearance of FGBC8 cells at passage 30 (A) and 46 (B) were analyzed respectively, using a microscope (Axio Vert, X100; ZEISS). FGBC8 cells were primarily epithelial-like cells and have been consistently subcultured. Scale bar: $200 \mu \mathrm{m}$. 
(A)

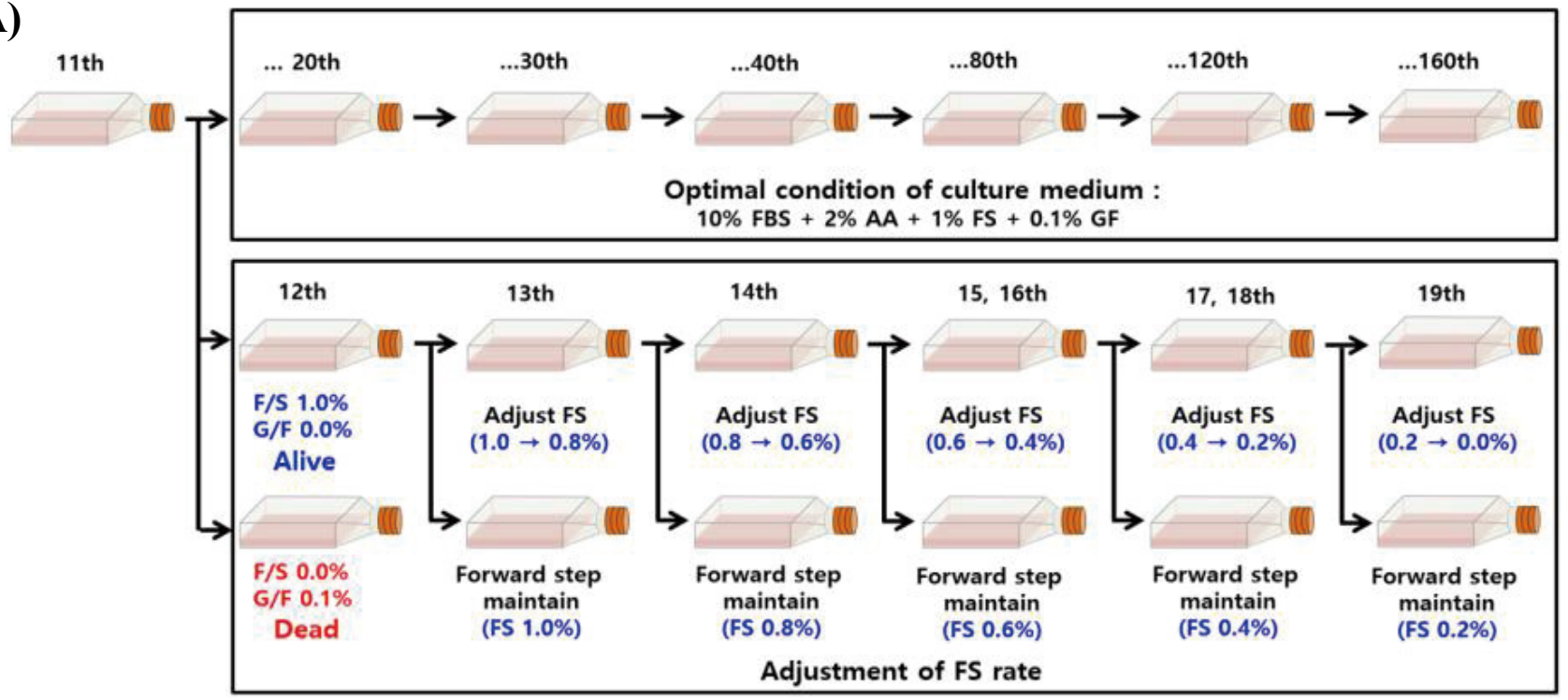

(B)

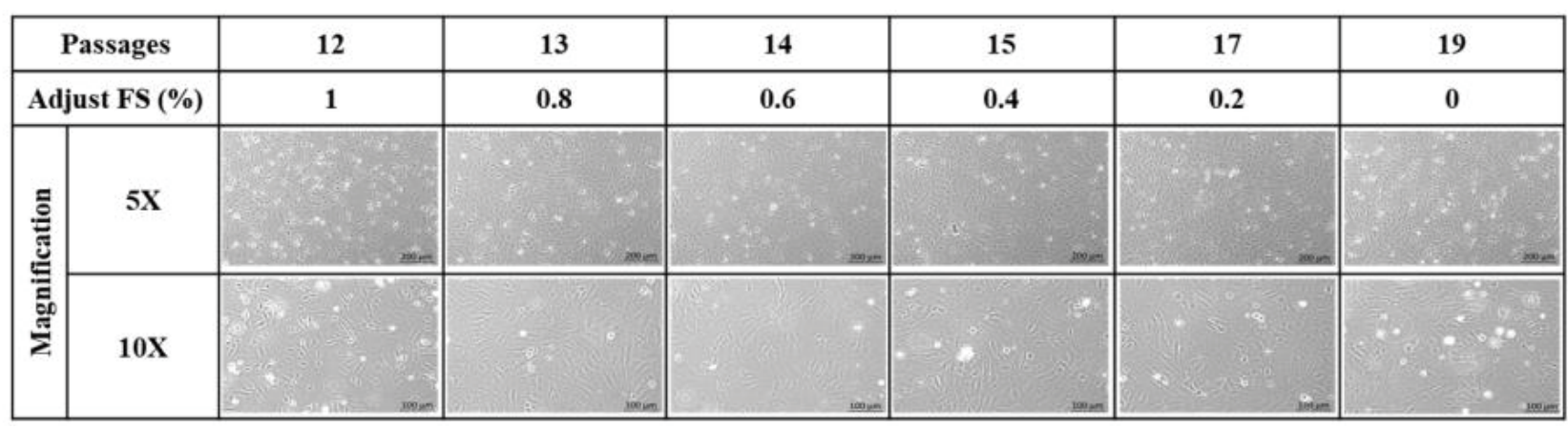

Fig. 2. The optimal conditions for culture medium and adjustments of fish serum (FS) addition. (A) FS was gradually decreased from $1.0 \%$ to $0 \%$, while growth factor (GF) was decreased from $0.1 \%$ to $0 \%$ to explore the conditions for optimal long-term maintenance of FGBC8 cells. (B) The monolayers of FGBC8 cells. Morphological appearance of FGBC8 cells at passages $12-19$ was analyzed using a microscope (Axio Vert, $\times 100 ;$ ZEISS). Although FS was gradually decreased from $1.0 \%$ to $0 \%$, there was no effect on the survival of the tested cells. Scale bar: $100 \mu \mathrm{m}$.

growth was assessed by cell proliferation assays and counting cell numbers with a hemocytometer. During the growth period, the number of cells increased, and the cells grew to confluence. Cell growth performance is shown in Fig. 3A and B. The FGBC8 cell density was $5 \times 10^{4} \mathrm{~mL}$ on day 1 and peaked at $17.7 \times 10^{4} \mathrm{~mL}$ on day 4 , with a doubling time of $73.8 \mathrm{~h}$. The cell morphology is shown in Fig. 3C.

Chromosome morphology of FGBC8 is shown in Fig. 4. The chromosome numbers of the FGBC8 cells were assessed at passage 49. The number of chromosomes in metaphase FGBC8 cells was 48.

To determine the transfection efficiency and gene expression of the FGBC8 cells, cells were transfected with plasmid pEGFP-c1 using JetPEI reagent. FGBC8 cells transfected with pEGFP-c1 exhibited a strong green fluorescent signal at $48 \mathrm{~h}$ after transfection. The transfection efficiency of FGBC8 cells was approximately 10\%-15\% (Fig. 5). Thus, FGBC8 cells are useful for exogenous gene expression, which is important for both basic research and biotechnological applications. 
(A)

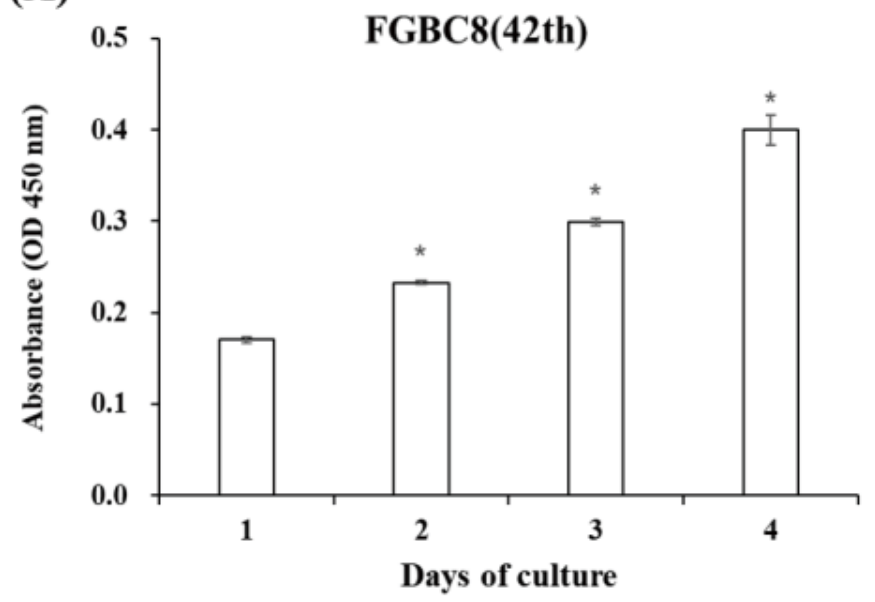

(B)

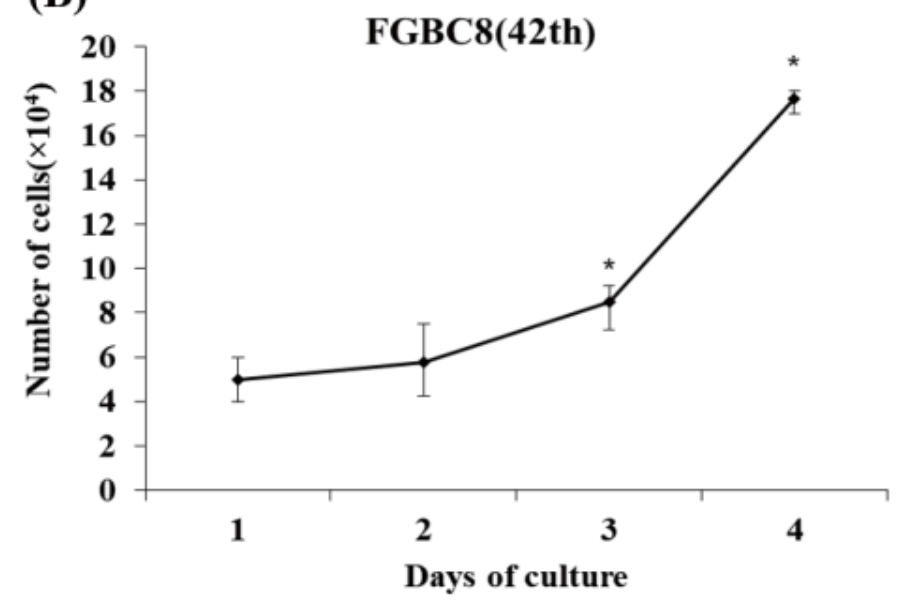

(C)

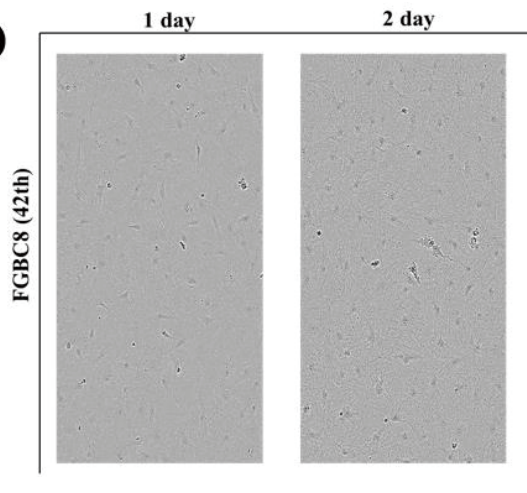

3 day

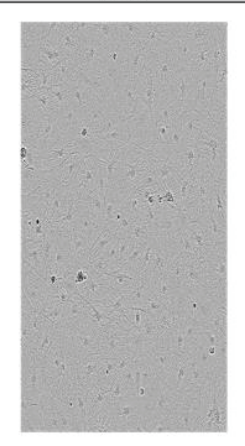

4 day

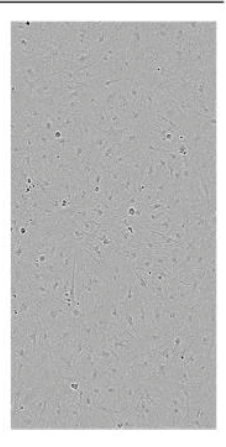

Fig. 3. Growth curve of the FGBC8 cells. Cell proliferation was observed using the growth curve from days $1-4$. The highest growth rate occurred on day 4 , and the population doubling time was $73.8 \mathrm{~h}$. The experiments were conducted three times independently. Error bars represent the standard deviation of five individual samples $(n=3)$. Data are presented as the mean $\pm S D$ based on three independent samples with three replicates per sample. Asterisks indicate significant differences $(*<0.05)$ compared to the control (Day 1$)$.

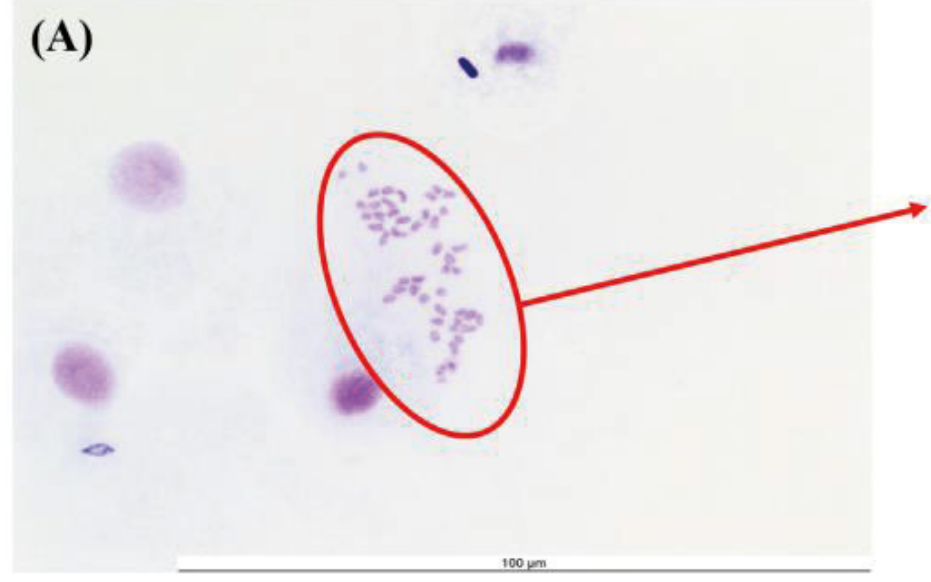

(B)

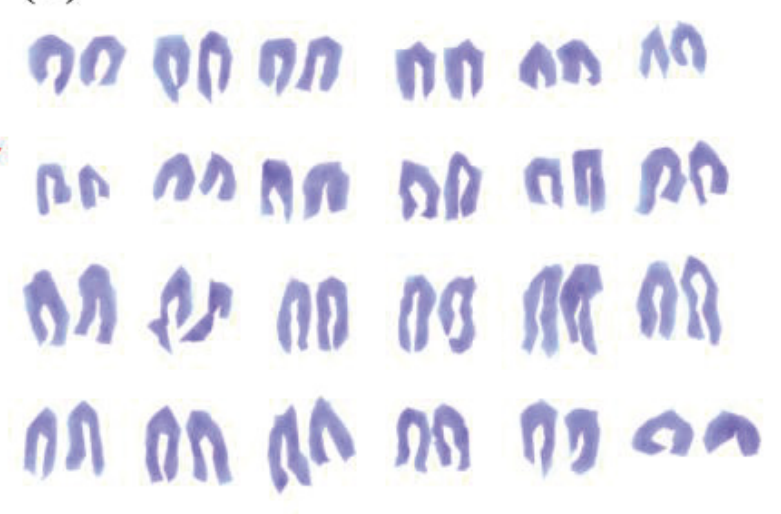

Fig. 4. Chromosome analysis of FGBC8 cells at passage 49. Metaphase chromosomes of FGBC8 cells were prepared on glass slides. The number of chromosomes was counted using a microscope (DE/EM6000B; Leica) after $8 \%$ Giemsa staining. (A) Chromosomes in metaphase FGBC8 cells. (B) Homologous chromosomes were paired according to their size. Images of FGBC8 cells containing a normal chromosome number ( $n=48$ ). 


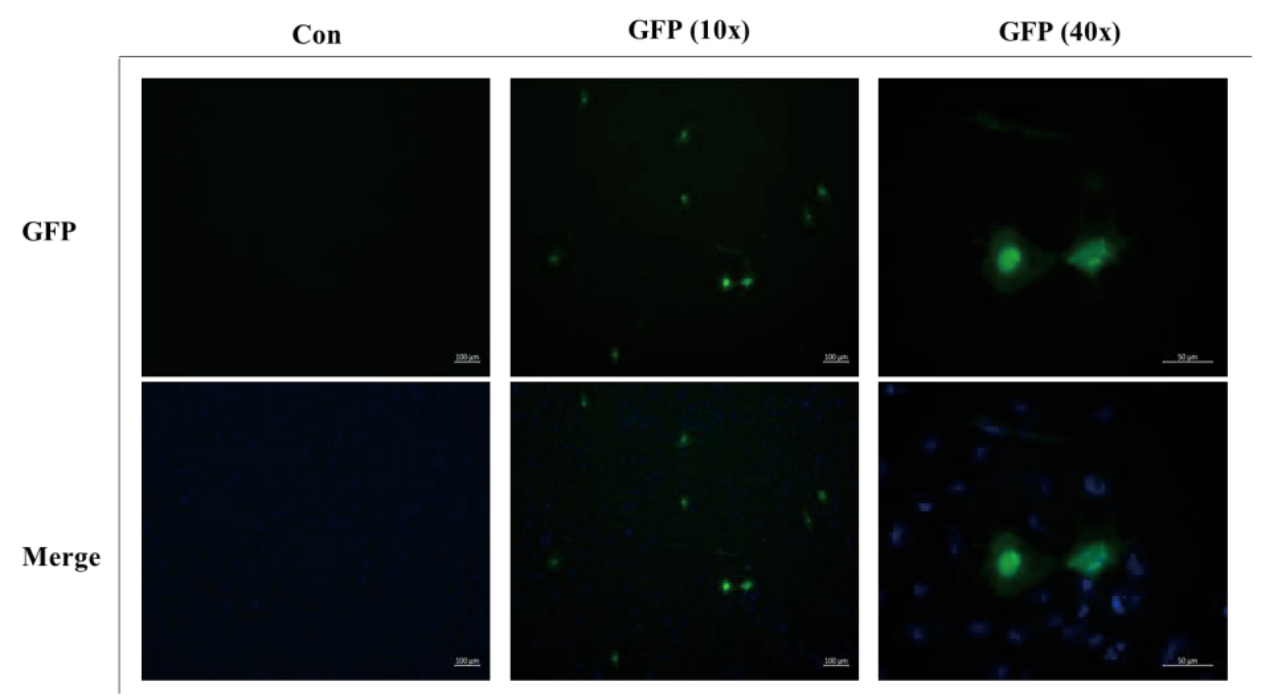

Fig. 5. Expression of the green fluorescent protein (GFP) gene in FGBC8 cells transfected with pEGFP-c1. Fluorescent micrographs of GFP expressed in transfected FGBC8 cells using pEGFP-c1 under a fluorescence microscope (Axio Vert A1; ZEISS). Transfection efficiency of FGBC8 cells was $10 \%-15 \%$. Scale bar: $100 \mu \mathrm{m}$.

\section{DISCUSSION}

In vitro cell culture is a vital tool in molecular biological research, providing an excellent model system for addressing research areas ranging from normal cellular physiology to drug screening and carcinogenesis (Ager-Wick et al., 2018).

Primary cells, isolated directly from animal tissue using enzymatic and/or mechanical methods, are often considered more biologically relevant than cell lines because the biological response may be closer to that in vivo (Ager-Wick et al., 2018). Protocols for preparing primary cell cultures should be optimized for each species and cell type of interest to mimic the characteristics to which a cell is adapted and obtain physiologically meaningful results (Ager-Wick et al., 2018).

In this study, novel olive flounder embryonic cell lines in vitro culture was developed and characterized in terms of their proliferation and transfection ability. Additionally, to establish the ideal conditions for long-term maintenance of primary embryonic cells, the effect of adjusting FS was evaluated.

In general, the media routinely used in fish cell culture are Glasgow MEM, Hank's MEM (HMEM), and L-15 (Lakra et al., 2011). Amino acid-rich nutrient media, such as L-15, that do not require $\mathrm{CO}_{2}$ buffering have been successfully used with fish cell lines; thus, $\mathrm{CO}_{2}$ incubators are not necessary, and cells can be grown conveniently in any undisturbed area. Due to this advantage, more than $80 \%$ of cell lines established after 1994 have used L-15 medium (Wang et al., 1995). In this study, L-15 medium and FS were useful for primary cell culture and promoted in vitro growth of olive flounder embryonic cells, as reported in other fish species, e.g., Japanese sea bass, red seabream, and turbot Scophthalmus maximus (Chen et al., 2003a; Chen et al., 2003b; Chen et al., 2004). Here, we demonstrated that FS in media is essential for primary cell culture of flounder embryonic cells. Our results can be used as a reference guide for primary embryonic cell cultures of other fish species.

The development of embryonic cell lines is a difficult process using primary cell culture methods. The methodology outlined in this study demonstrates that embryonic cells isolated from blastula- 
stage flounder embryos can survive and retain comparable morphology in subculture for a long time. Furthermore, FGBC8 primary embryonic cells will allow further analyses of expression of immune-related genes using mitogens such as lipopolysaccharide, Poly I:C, flagellin, and interferon- $\gamma$ and will further our basic understanding of immune responses. Further study of FGBC8 characteristics will allow full exploitation of the potential of this new embryonic cell line, and we encourage use of our method to explore and develop it as a model.

\section{REFERENCES}

Ager-Wick E, Hodne K, Fontaine R, von Krogh K, Haug TM, Weltzien FA (2018) Preparation of a high-quality primary cell culture from fish pituitaries.J Vis Exp 138:58159.

Chen SL, Ren GC, Sha ZX, Shi CY (2004) Establishment of a continuous embryonic cell line from Japanese flounder Paralichthys olivaceus for virus isolation. Dis Aquat Organ 60:241-246.

Chen SL, Sha ZX, Ye HQ(2003a) Establishment of a pluripotent embryonic cell line from sea perch (Lateolabrax japonicus) embryos. Aquaculture 218:141-151.

Chen SL, Ye HQ, Sha ZX, Hong Y (2003b) Derivation of a pluripotent embryonic cell line from red sea bream blastulas. J Fish Biol 63:795-805.

Ghosh D, Dasmahapatra AK, Ray AK (1995) Primary culture of prawn hepatocytes in serum free media. In vitro Cell Dev Biol-Anim 3:811-813.

Hasoon M (2018) Evaluation of the isolation protocols of primary cells from common carp (Cyprinus carpio L.) skin tissue. Iraqi J Vet Sci 32:119-125.

Kang MS, Oh MJ, Kim YJ, Kawai K, Jung SJ (2003) Establishment and characterization of two new cell lines derived from flounder, Paralichthys olivaceus (Temminck \& Schlegel). J Fish Dis 26:657-665.

Kasai H, Yoshimizu M (2001) Establishment of two Japanese flounder embryo cell lines. Bull Fish Sci, Hokkaido Univ 52:67-70.

Kim JW, Kim EG, Kim DH, Shim SH, Park CI (2013) Molecular identification and expression analysis of the $\mathrm{CC}$ chemokine gene in rock bream (Oplegnathus fasciatus) and the biological activity of the recombinant protein. Fish Shellfish Immunol 34:892-901.

Kim JW, Oh BG, Kim J, Kim DG, Nam BH, Kim YO, Park JY, Cheong J, Kong HJ (2018) Development and characterization of a new cell line from olive flounder Paralichthys olivaceus. Dev Reprod 22:225-234.

Lakra WS, Raja-Swaminathan T, Joy KP (2011) Development, characterization, conservation and storage of fish cell lines: A review. Fish Physiol Biochem 37:1-20.

Tong SL, Miao HZ, Li H (1998) Three new continuous fish cell lines of SPH, SPS and RSBF derived from sea perch (Lateolabrax japaonicus) and red sea bream (Pagrosomus major). Aquaculture 169:143-151.

Wang R, Neumann NF, Shen Q, Belosevic M (1995) Establishment and characterization of a macrophage cell line from the goldfish. Fish Shellfish Immunol 5:329-346.

Wang SR, Renaud G, Infante J, Catala D, Infante R (1985) Isolation of rat hepatocytes with EDTA and their metabolic functions in primary culture. In vitro Cell Develop Biol 21:526-530.

Wang T, Chen X, Xu K, Zhang B, Huang D, Yang J (2020) Apoptosis induction and detection in a primary culture of sea cucumber intestinal cells.J Vis Exp 21:60557.

Zheng Y, Peng LM, You F, Zou YX, Zhang PJ, Chen SL (2015) Establishment and characterization of a fish-cell line from the brain of Japanese flounder Paralichthys olivaceus. J Fish Biol 87:115-122. 